\title{
Factors Contributing to Student Fortitude in Distance Learning (Descriptive Study at AKPER Giri Satria Husada Wonogiri)
}

\author{
Kristiana Puji Purwandari ${ }^{1}$, Nugroho Priyo $\mathrm{H}^{2}$, Y. Wahyu Nugroho ${ }^{3}$, Y. Wahyunti \\ Kristiningtyas ${ }^{4}$ \\ Akper Giri Satria Husada Wonogiri \\ \{kristiana_pp@yahoo.com, Npriyo1120@gmail.com\}
}

\begin{abstract}
Education in the current era is facing global challenges that coincide with the socio-economic crisis around the world due to the spread of covid-19. This pandemic incident caused like or dislike the implementation of education, which originally had to be carried out face-to-face, to be disrupted because it was feared that it would worsen the transmission and pandemic of Covid-19. The online distance learning policy (online) is a logical choice so that learning can still be implemented. This requires students to have basic skills in the use of technology and information platforms in order to access learning from teachers. This research was conducted with the aim of finding out how far the students were fortitude in carrying out distance learning during the Covid-19 pandemic. This research is categorized as qualitative research in which data is extracted through a questionnaire to students at Akper Giri Satria Husada Wonogiri. The Likert scale was used to collect data from respondents, totaling 133 students. Furthermore, the data were analyzed using descriptive analysis techniques. The results showed that the factors that played a role in student resilience in distance learning during the Covid-19 pandemic were included in the good category, whether it was seen from the knowledge of information technology, facilities and infrastructure, the variety of media and applications used, the benefits of the media and IT-based applications, as well as mastery of lecturers in IT.
\end{abstract}

Keywords: Character Fortitude; students; distance learning

\section{Introduction}

Currently, the Corona Virus Disease (Covid-19) outbreak is rife, which has hit more than 200 countries in the world The Covid-19 initially became an epidemic in Wuhan, China since December 2019 [1], then hit 36 countries including the United States [2]. Therefore, on March 11, 2020, the Director-General of WHO, Tedros Adhanom Ghebreyesus, officially stated that the COVID-19 had become a global pandemic [3], and even Bill Gates referred to it as the pandemic of this century [4]. Anticipating the transmission of the virus, the government has issued various policies, such as isolation, social and physical distancing to large-scale social restrictions. This condition requires residents to stay at home, work, worship and study at home. As a result of the pandemic, it requires educational institutions to innovate in the learning process and provides challenges for educational institutions, especially higher education. One of these alternative forms is to conduct distance learning in networks (online) [5]. Online learning system or known as e-learning is a form of utilizing technology to support 
the teaching and learning process. Online distance learning makes it easy for teachers to provide material and discussion at any time via the internet. Support in the form of introduction and training to implement a distance learning system in a network is absolutely necessary, for both students and teachers [6].

Several arguments are associated with e-learning. Accessibility, affordability, flexibility, learning pedagogy, life-long learning, and policy are some of the arguments related to online pedagogy. It is said that online mode of learning is easily accessible and can even reach to rural and remote areas [7]. Applications such as zoom, google meet are supported by google form which are chosen to help students and lecturers as teachers conduct lectures online [8]. Giri Satria Husada Nursing Academy Wonogiri as a higher education institution for nursing and midwifery education in Wonogiri district also implements distance learning in its education system starting April 2020. This distance learning policy is related to the covid-19 pandemic around the world, including in Wonogiri district, Indonesia. The implementation of distance learning at Akper Giri Satria Husada starting April 2020 has not been implemented $100 \%$. Therefore, it is necessary to study as a preliminary research to determine the resilience of students in distance learning so that the factors that play a role in distance learning are needed in relation to the level of student resilience in order to achieve the expected learning outcomes.

There were several factors that became obstacles to early research on student persistence in distance learning. Preliminary studies include student IT knowledge [9], facilities on campus [10], various media / applications used, and lecturer teaching methods. So it is necessary to do research to find out the factors that contribute to student resilience in distance learning at Akper Giri Satria Husada Wonogiri. Based on the description above, the objectives of this study are (1) to analyze the effect of student IT knowledge on teaching methods of lecturers in distance learning, (2) to analyze students' IT knowledge on student learning in distance learning, (3) to analyze the effect of student learning facilities. toward lecturer teaching methods in distance learning, (4) to analyze the effect of student learning facilities on student resilience in distance learning, (5) to analyze the effect of various application media on teaching methods of lecturers in distance learning, (6) to analyze various application media against student resilience in distance learning, and (7) to analyze the effect of lecturer teaching methods on student resilience in distance learning.

\section{Method}

The research method used a quantitative approach with a causality design. The population of this study were 200 students of the Giri Satria Husada Wonogiri Indonesia nursing academy. The sampling technique used the Slovin purposive sampling formula so that 133 people were assigned as the research sample. The data collection technique used a questionnaire. The questionnaire instrument with a Likert scale was used to capture research data including a student ability questionnaire with 6 statement items, a learning facilities questionnaire with 6 (six) statements, a questionnaire for various media applications with 5 (five) statements, a lecturer teaching method instrument with 6 statements, and an instrument. student tenacity level with 6 statements [11]. Data analysis used SEM analysis with warp PLS. PLS is a method that uses the SEM (Structural Equation Modeling) model which is used to solve the problem of the relationship between complex variables but the data sample size is small [12]. 


\section{Result and Discussion}

According to [13], Goodness of fit measures the suitability of observational / actual inputs, with the prediction of the proposed model. There are 3 criteria for model fit indices or model suitability, namely the Average Path Coefficient (APC), Average R-square (ARS) and Average Variant Inflation Factor (AVIF). Following are the results of the fit Model output: The urgency of implementing character education in Budi Mulia International High School is because schools want to create students who are not only intelligent in their cognitive aspects, but also superior in their affective side.

Table 1. Fit Model

\begin{tabular}{lcc}
\hline Model & Fit Indices & P Values \\
\hline APC & 0.289 & $\mathrm{P}<0.001$ \\
ARS & 0.628 & $\mathrm{P}=0.001$ \\
AVIF & 1.516 & Good If $<0.5$ \\
\hline
\end{tabular}

From the output results in table 1 shows that the model indicator is fit with an average path coefficient (APC) $0.001<0.05$. While the Average R-squared (ARS) $0.001<0.05$. Likewise, the AVIF value is $1.516<5$, which means that the model has a good fit so that there is no Multicollinearity problem between exogenous variables. Convergent validity is assessed based on the correlation between the indicator score and the construct score (outer loading). According to Chin (1998), each indicator can be said to be valid if its outer loading value is greater than 0.7 . However, for research in the early stages of developing a measurement scale the loading value of 0.60 is considered sufficient. If an indicator does not meet these criteria, then the indicator is declared invalid and needs to be removed from the model.

Table 2. Outer Loading Value

\begin{tabular}{lccl}
\hline \multicolumn{1}{c}{ Variables } & Indicator & Outer Loading & Conclusion \\
\hline Student's IT knowledge (X1) & X1.1 & 0.772 & Valid \\
& X1.2 & 0.663 & Valid \\
& X1.3 & 0.740 & Valid \\
& X1.4 & 0.781 & Valid \\
& X1.5 & 0.764 & Valid \\
& X1.6 & 0.707 & Valid \\
Facilities (X2) & X2.1 & 0.567 & Valid \\
& X2.2 & 0.637 & Valid \\
& X2.3 & 0.727 & Valid \\
& X2.4 & 0.548 & Valid \\
Variety of media/applications & X2.5 & 0.702 & Valid \\
(X3) & X2.6 & 0.563 & Valid \\
& X3.1 & 0.852 & Valid \\
& X3.3 & 0.692 & Valid \\
& X3.4 & 0.756 & Valid \\
& & & Valid \\
\hline
\end{tabular}




\begin{tabular}{lccc}
\hline \multirow{2}{*}{ Lecture Teaching methods (X4) } & X3.5 & 0.713 & Valid \\
& X4.1 & 0.670 & Valid \\
& X4.2 & 0.645 & Valid \\
X4.3 & 0.799 & Valid \\
X4.4 & 0.811 & Valid \\
X4.5 & 0.792 & Valid \\
X4.6 & 0.837 & Valid \\
& Y1 & 0.867 & Valid \\
& Y2 & 0.677 & Valid \\
& Y3 & 0.850 & Valid \\
& Y4 & 0.812 & Valid \\
& Y5 & 0.814 & Valid \\
& Y6 & 0.757 & Valid \\
\hline
\end{tabular}

According to [13], to measure a construct in research it must meet an outer loading value above 0.5 which is still acceptable. Table 2 shows that all indicators have an outer loading value of more than 0.5 , then all research variable indicators are valid and can be used for structural modeling. A construct is said to be reliable seen from its composite reliability value and Cronbach's alpha value. The construct is declared reliable if the composite reliability and Cronbach's alpha value is above 0.70 .

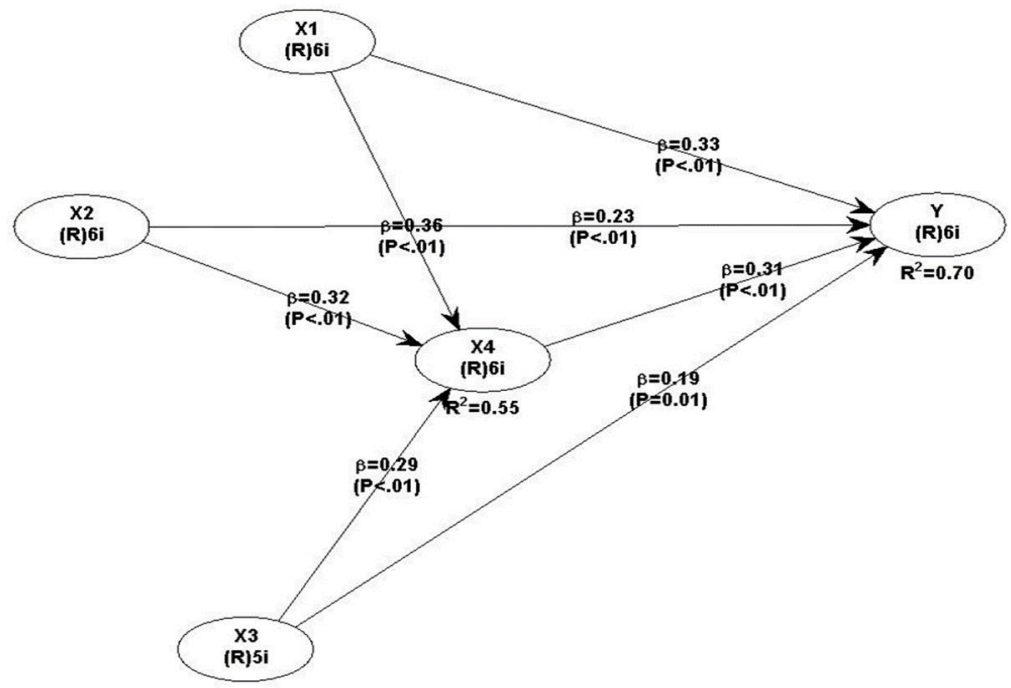

Fig 1. Path Schema

Based on Table 3, it shows that the Composite Reliability value is more than 0.7 , so it can be concluded that the research instrument above is reliable. Based on Table 3, the results of the warpPLS output show that the output value of composite reliability, and average variances extract $(\mathrm{AVE})>0.5$. These results are in accordance with the required criteria. 
Table 3. Reliability Test

\begin{tabular}{cccc}
\hline Variables & $\begin{array}{c}\text { Cronbach's } \\
\text { Alpha }\end{array}$ & $\begin{array}{c}\text { Composite } \\
\text { Reliability }\end{array}$ & Information \\
\hline X1 & 0.833 & 0.878 & Reliable \\
X2 & 0.688 & 0.794 & Reliable \\
X3 & 0.795 & 0.860 & Reliable \\
X4 & 0.853 & 0.892 & Reliable \\
Fortitude (Y) & 0.885 & 0.913 & Reliable \\
\hline
\end{tabular}

Table 4. Path Coefficient and P Values

\begin{tabular}{lccl}
\hline Correlation & Path Coefficient & P-values & Conclusion \\
\hline $\mathrm{X} 1 \rightarrow \mathrm{X} 4$ & 0.355 & $<0.001$ & H1 Accepted \\
$\mathrm{X} 1 \rightarrow \mathrm{Y}$ & 0.330 & $<0.001$ & H2 Accepted \\
$\mathrm{X} 2 \rightarrow \mathrm{X} 4$ & 0.317 & $<0.001$ & H3 Accepted \\
$\mathrm{X} 2 \rightarrow \mathrm{Y}$ & 0.228 & 0.005 & H4 Accepted \\
$\mathrm{X} 3 \rightarrow \mathrm{X} 4$ & 0.295 & $<0.001$ & H5 Accepted \\
$\mathrm{X} 3 \rightarrow \mathrm{Y}$ & 0.194 & 0.014 & H6 Accepted \\
$\mathrm{X} 4 \rightarrow \mathrm{Y}$ & 0.307 & $<0.001$ & H7 Accepted \\
\hline
\end{tabular}

The following are the results of hypothesis testing which can be explained as follows:

a. H1 testing of student IT knowledge affects the teaching methods of lecturers The results of the calculations in table 4 show that the resulting P-values are $0.001<0.05$ and the path coefficient is 0.355 which is positive. $p$ value of 0.001 is smaller than 0.05 which means significant, meaning that $\mathrm{H} 1$ is accepted.

b. H2 testing student IT knowledge affects student resilience The results of the calculations in table 4 show that the resulting $\mathrm{P}$-values are $0.014<0.05$ and the path coefficient is 0.330 which is positive. $p$ value of 0.014 is smaller than 0.05 which means significant, meaning that $\mathrm{H} 2$ is accepted.

c. Testing H3 facilities affects the teaching methods of lecturers The results of the calculations in table 4 show that the resulting $\mathrm{P}$-values are $0.001<0.05$ and the path coefficient is 0.317 which is positive. $p$ value of 0.001 is smaller than 0.05 which means significant, meaning that $\mathrm{H} 3$ is accepted.

d. Testing $\mathrm{H} 4$ facilities affects student resilience. The results of the calculations in table 4 show that the resulting P-values are $0.005<0.05$ and the path coefficient is 0.228 , which is positive. $p$ value of 0.005 is smaller than 0.05 which means significant, meaning that $\mathrm{H} 4$ is accepted.

e. Testing H5 media / application variations have an effect on teaching methods The results of the calculations in table 4 show that the resulting P-values are $0.001<0.05$ and the path coefficient is 0.295 which are positive. $p$ value of 0.001 is smaller than 0.05 which means significant, meaning that $\mathrm{H} 5$ is accepted

f. Testing H6 media / application variations have an effect on student resilience. The results of the calculations in table 4 show that the resulting P-values are $0.014<0.05$ and the path coefficient is 0.194 which is positive. $p$ value of 0.014 is smaller than 0.05 which means significant, meaning that $\mathrm{H} 6$ is accepted.

g. Testing $\mathrm{H} 7$ teaching methods affects student resilience. The calculation results in table 4 show that the resulting P-values are $0.001<0.05$ and the path coefficient is 0.307 which is positive. $p$ value of 0.001 is smaller than 0.05 which means significant, meaning that $\mathrm{H} 7$ is accepted 
Based on the results of the study, information was obtained that students' IT knowledge had an effect on the level of student resilience in distance learning. This is consistent with research by [14] which found that the ability of students and teachers is an important factor in distance learning with a percentage of $60 \%$. The learning facility factor also plays a role in distance learning because there are adequate learning facilities such as ownership of a laptop or smartphone, the internet as a learning resource, and virtual laboratory facilities strongly support distance learning. The results of this study indicate that learning facilities affect the level of student resilience in distance learning.

The variety of media or applications such as zoom, lark meeting, google classroom, and google form also affects the level of tenacity of students in distance learning. The results of this study indicate that there is a significant effect of lecturer teaching methods on the level of student resilience in distance learning. This is indicated by a coefficient of 0.194 with a $\mathrm{p}$ value of 0.014 which is $<0.05$. The results of this study are in accordance with the results of [15] study that the importance of teaching methods is to create interactions between students and lecturers in distance learning. The essence of interaction among students, teachers, and content is well understood and is referenced in many theories of education, especially constructivism [16]. The results of the coefficient of determination of this study using SEM analysis are shown as follows:

Table 5. R-squared

\begin{tabular}{ccccc}
\hline $\mathbf{X 1}$ & $\mathbf{X 2}$ & $\mathbf{X 3}$ & $\mathbf{X 4}$ & $\mathbf{Y}$ \\
\hline & & & 0.554 & 0.702 \\
\hline
\end{tabular}

Based on the results of the output in table 5 , the $\mathrm{R}$ squared value of 0.554 is obtained, which means that the influence of variables $\mathrm{X} 1, \mathrm{X} 2, \mathrm{X} 3$, and $\mathrm{X} 4$ on student resilience $(\mathrm{Y})$ is $70.2 \%$ and the remaining $29.8 \%$ is influenced by other variables outside of this research model. Indirect effects can be analyzed by structural model equations (SEM) because SEM is considered as a unit of simultaneous estimates in regression when an independent variable in one regression and at the same time becomes a dependent variable in another regression [17].

\section{Conclusion}

Based on the results of the data analysis described in the previous chapter, it can be concluded that the results of this study are as follows:

a. Knowledge of student IT has a positive effect on lecturer teaching methods, so H1 is accepted. This shows that the higher the level of student IT knowledge. give influence to lecturer teaching methods.

b. Student IT knowledge has a positive effect on the level of student resilience in distance learning, so $\mathrm{H} 2$ is accepted. This shows that the higher the level of student IT knowledge, the higher the level of student resilience in distance learning.

c. Facilities have a positive effect on lecturer teaching methods, so H3 is accepted. This shows that the more complete the facilities, the effect on the teaching methods of the lecturers.

d. Facilities have a positive effect on the level of student resilience in distance learning, so $\mathrm{H} 4$ is accepted. This shows that the more complete the facilities, the higher the level of student resilience in distance learning. 
e. The variety of media / applications has a positive effect on the teaching methods of lecturers, so H5 is accepted. This shows that the more supporting media / applications have an influence on the teaching methods of lecturers.

f. The variety of media / applications has a positive effect on the level of student resilience in distance learning, so H6 is accepted. This shows that the more supporting media / applications, the higher the level of student resilience in distance learning.

g. The teaching method of the lecturer has a positive effect on the level of student resilience in distance learning, so $\mathrm{H} 7$ is accepted. This shows that the better the teaching method of the lecturer, the higher the level of student resilience in distance learning

The limitation in this study is the $\mathrm{R}$ squared value of 0.702 or $70.2 \%$ which indicates that there are other variables not used in this study that have an influence on the resilience level of students in distance learning.

The author proposes the following: (1) Future research is expected to pay more attention to indicators as measures of research variables so that it can minimize the outer loading value which is still below 0.7 ; (2) Future research is expected to use other variables that can become intervening variables to strengthen the relationship between exogenous variables and endogenous variables such as ease of use of applications, communication, and evaluation.

\section{References}

[1] A. L. Phelan, R. Katz, and L. O. Gostin, "The Novel Coronavirus Originating in Wuhan, China: Challenges for Global Health Governance," JAMA - J. Am. Med. Assoc., vol. 323, no. 8, pp. 709710, 2020, doi: 10.1001/jama.2020.1097.

[2] R. M. Burke et al., "Active Monitoring of Persons Exposed to Patients with Confirmed COVID-19 — United States, January-February 2020,” MMWR. Morb. Mortal. Wkly. Rep., vol. 69, no. 9, pp. 245-246, 2020, doi: 10.15585/mmwr.mm6909e1.

[3] A. A. Anjorin, "The coronavirus disease 2019 (COVID-19) pandemic: A review and an update on cases in Africa," Asian Pac. J. Trop. Med., vol. 13, no. 5, pp. 199-203, 2020, doi: 10.4103/19957645.281612 .

[4] B. Gates, "New engla nd journal," pp. 1677-1679, 2020.

[5] D. Jamaluddin, T. Ratnasih, H. Gunawan, and E. Paujiah, "Pembelajaran Daring Masa Pandemik Covid-19 Pada Calon Guru : Hambatan, Solusi dan Proyeksi," Karya Tulis Ilm. UIN Sunan Gunung Djjati Bandung, pp. 1-10, 2020, [Online]. Available: http://digilib.uinsgd.ac.id/30518/.

[6] M. Dimyati A, D. Suwardiyanto, H. Yuliandoko, and V. Arief W, "Pemanfaatan Teknologi Sebagai Media Pembelajaran Daring (on Line) Bagi Guru Dan Siswa Di Smk Nu Rogojampi," J-Dinamika, vol. 2, no. 2, 2018, doi: 10.25047/j-dinamika.v2i2.565.

[7] S. Dhawan, "Online Learning: A Panacea in the Time of COVID-19 Crisis," J. Educ. Technol. Syst., vol. 49, no. 1, pp. 5-22, 2020, doi: 10.1177/0047239520934018.

[8] I. Suhada et al., "Pembelajaran Daring Berbasis Google Classroom Mahasiswa Pendidikan Biologi Pada Masa Wabah Covid-19," Digit. Libr. UIN Sunan Gunung Jati, vol. 2019, pp. 1-9, 2020, [Online]. Available: http://digilib.uinsgd.ac.id/30584/.

[9] R. H. Syah, "Dampak Covid-19 pada Pendidikan di Indonesia: Sekolah, Keterampilan, dan Proses Pembelajaran," SALAM J. Sos. dan Budaya Syar-i, vol. 7, no. 5, 2020, doi: 10.15408/sjsbs.v7i5.15314

[10] E. Ndjebakal Souck and G. Nji, "The Effects of School Facilities on Internal Efficiency: The Case of Selected Bilingual Secondary Schools in Yaounde Centre," World J. Res. Rev., vol. 4, no. 4, pp. 41-48, 2017, [Online]. Available: www.wjrr.org.

[11] D. R. Van Tongeren et al., "Development and Validation of a Measure of Spiritual Fortitude," Psychol. Trauma Theory, Res. Pract. Policy, no. January 2020, 2019, doi: 10.1037/tra0000449. 
[12] J. F. Hair, C. M. Ringle, and M. Sarstedt, "PLS-SEM: Indeed a silver bullet," J. Mark. Theory Pract., vol. 19, no. 2, pp. 139-152, 2011, doi: 10.2753/MTP1069-6679190202.

[13] Ghozali, I\& Hengky Latan. 2012. Partial Least Squares Konsep, Metode dan Aplikasi menggunakan Program Warp PLS2 untuk Penelitian Empiris. Semarang : BP Universitas Diponegoro.

[14] B. Mulyanti, W. Purnama, and R. E. Pawinanto, "Distance learning in vocational high schools during the covid-19 pandemic in West Java province, Indonesia," Indones. J. Sci. Technol., vol. 5, no. 2, pp. 271-282, 2020, doi: 10.17509/ijost.v5i2.24640.

[15] M. Sadeghi, “Manijeh Sadeghi 1,” Int. J. Reserach Englissh, no. March, pp. 80-88, 2019.

[16] A. G. Picciano, "Theories and frameworks for online education: Seeking an integrated model," Online Learn. J., vol. 21, no. 3, pp. 166-190, 2017, doi: 10.24059/olj.v21i3.1225.

[17] L. De Paepe, J. De Vos, V. Van Acker, and F. Witlox, "Changes in travel behavior during the transition from secondary to higher education: A case study from Ghent, Belgium,” J. Transp. Land Use, vol. 11, no. 1, pp. 477-498, 2018, doi: 10.5198/jtlu.2018.1113. 